\title{
Drivers of rice production: evidence from five Sub-Saharan African countries
}

\author{
Sultana Nasrin ${ }^{1 *}$, Johanna Bergman Lodin ${ }^{2}$, Magnus Jirström³ ${ }^{3}$ Björn Holmquist ${ }^{1}$, Agnes Andersson Djurfeldt ${ }^{3}$ \\ and Göran Djurfeldt ${ }^{4}$
}

\begin{abstract}
Background: In spite of considerable rice production gains over the past 50 years, Sub-Saharan Africa is becoming increasingly dependent on rice imports as demand is outpacing domestic supply. The serious economic and social strains caused by this have urged national leaders to address production deficits. The aim of this article is to analyse and discuss the drivers behind recent changes in rice production in Africa South of the Sahara, focusing on Ghana, Malawi, Nigeria, Tanzania and Mozambique. Considering the period 2002-2008, we model production performance and changes in production amongst 317 rice-growing households using multilevel and longitudinal data. We evaluate and discuss the role of three key processes: the role of commercial drivers, farm technology and macro-level conditions.

Results: We show that until 2002, production was driven by a combination of the three key processes considered, while during the period 2002-2008, production increases were primarily associated with area expansion and commercial drivers. This suggests that production lately has been more driven by processes of extensification than intensification. We also note that in none of the periods considered, the share of the state budget allocated to agriculture had a significant effect on production and that recent developments do not give any obvious support for an Asianstyle state-driven Green Revolution in rice in Sub-Saharan Africa.
\end{abstract}

Conclusions: The role of commercialization in explaining changes in production suggests that policies strengthening food staple markets in the sub-continent hold great potential for driving rice production in the near future. Due to the scarcity of available land, the possibilities of further growth in the rice sector are limited without an intensification of production. Hence, farmers also need to access new farm technology, and positive development of rice production would in turn contribute to an improvement of food security.

Keywords: Rice production, Rice consumption, Africa, Change in production, Commercialization, New technology, Macro-level conditions, Longitudinal data, Multilevel data

\section{Background}

Global demand for agricultural products is expanding rapidly and the demand for food products is foreseen to continue to grow for several decades as a result of a combination of population growth, rising per capita incomes and urbanization [1]. In developing countries, approximately $60 \%$ of total calories consumed are derived directly from cereals with values exceeding $80 \%$ in the poorest countries [2].

\footnotetext{
*Correspondence: sultana.nasrin@stat.lu.se

1 Department of Statistics, Lund University, P.O. Box 743, S-220 07 Lund, Sweden

Full list of author information is available at the end of the article
}

Among the cereals, rice is the most important source of calories for humans. While per capita consumption is declining in parts of Asia, the demand for rice has increased considerably in Sub-Saharan Africa (SSA) since 1995 and is growing more rapidly there than in any other continent [3]. Increased rice consumption can be traced to a combination of population growth, urbanization, ${ }^{1}$ changing consumer preferences and economic development [see e.g. 3, 5, 6]. Although rice production in SSA has increased substantially

\footnotetext{
${ }^{1}$ Many urban women dwellers when entering the extra-household labour force substitute easily prepared rice for time-consuming traditional staple foods like cassava, sorghum and millet [4].
}

C Biomed Central

(c) 2015 Nasrin et al. This article is distributed under the terms of the Creative Commons Attribution 4.0 International License (http://creativecommons.org/licenses/by/4.0/), which permits unrestricted use, distribution, and reproduction in any medium, provided you give appropriate credit to the original author(s) and the source, provide a link to the Creative Commons license, and indicate if changes were made. The Creative Commons Public Domain Dedication waiver (http://creativecommons.org/ publicdomain/zero/1.0/) applies to the data made available in this article, unless otherwise stated. 
over the past 50 years ${ }^{2}$, demand has outpaced domestic supply resulting in increasing imports [7-9]. The share of imports in African rice consumption has grown by $2 \%$ per year over the past 50 years and reached $43 \%$ in 2009 [10]. Indeed, almost one-third of the rice traded on the world market in 2011, or 11.8 million tons, was imported by African countries, compared to 0.5 million tons in 1961. Countries with international ports and populous cities, such as many West African countries, tend to be particularly large importers [10]. A recent estimate suggests that rice imports cost Africa more than US $\$ 4.3$ billion annually [11]. The serious economic and social strains caused by the dependence on rice imports have urged national leaders, supported by international development partners, to address production deficits by strengthening the domestic rice sector [6, 12]. Expected positive effects, apart from improvement in balance of payments, include enhanced food security and reduced poverty among both producers and consumers. ${ }^{3}$

The aim of this article is to analyse and discuss the drivers of recent development in rice production in SSA, focusing on Ghana, Malawi, Nigeria, Tanzania and Mozambique. We model production performance and changes in production amongst 317 rice-growing households, considering the period 2002-2008. Specifically, we evaluate and discuss the role of three key processes: the role of commercial drivers, farm technology and statespecific conditions (including agrarian policies). Our findings can inform future strategies and policies for capacity development in the rice value chain.

In the following sections, after a brief presentation of the role of rice in the five countries, we introduce the data and the general modelling strategy. Thereafter, we outline key theoretical perspectives that inform this article. We then present descriptive statistics pertaining to select socio-demographic characteristics of the panel households as well as the variables that we use in our modelling. In the following section, we introduce the three models. Thereafter, we present and discuss the results, specifically considering the commercial, technology and policy drivers behind changes in rice production. The article concludes by outlining the implications of these findings for agricultural policy and practice in the region.

\section{Rice production and consumption in the five case study countries}

Rice is becoming increasingly important in the five countries considered in this study, with Ghana and

\footnotetext{
${ }^{2}$ From an annual production of 2.8 million tons in 1961 to an estimated 16.6 million tons (both on milled basis) in $2011[3,5,6]$.

${ }^{3}$ On the other hand, as Demont [10] points out, tax revenues from imported food, including rice, are important for several African countries.
}

Nigeria currently in the lead in terms of per capita consumption (Fig. 1). This is in line with reports that rice is much more important in West Africa than in the other regions of SSA [12]. However, Tanzania, as the country ranked second (after Madagascar) within Eastern, Central and Southern Africa in terms of rice production and consumption [13], has become a clear runner-up in these sub-regions over the past few years. In Fig. 1 we can see that the per capita consumption has been increasing steadily over the last three decades in Ghana, Nigeria, Tanzania and Mozambique. In these four countries, rice is today ranked between number three and five in terms of importance vis-à-vis other crops consumed, ${ }^{4}$ and represents approximately $10 \%$ of daily caloric intake [14-20]. Only in Malawi is rice reported to be a crop of minor importance, which is also reflected by rice and wheat together accounting for only $4 \%$ of daily caloric intake [21].

Farmers in these countries, especially in Nigeria and Tanzania, have responded to the increasing demand for rice, as reflected in upward trends in aggregate production [22]. When adjusting for population increases (Fig. 2), the production trends are much less impressive, however, and as Fig. 3 shows, many of the countries are also becoming increasingly dependent on rice imports, fuelled by growing production-to-consumption gaps.

\section{Methods}

\section{Introduction to the data set}

The data derives from a longitudinal survey conducted in 2002 and 2008 within the framework of the Africa and Intensification (Afrint) project ${ }^{5}$, which focused on a group of countries located in what can be described as the African 'maize and cassava belt. Nine countries were purposively selected-Ethiopia, Ghana, Kenya, Malawi, Nigeria, Tanzania, Uganda, Zambia and Mozambique [23, 24]. The survey covered more than 4000 randomly sampled households in 103 purposively sampled villages. Informed consent was received from each survey participant. The project adhered to the Swedish Research Council's ethical guidelines, and recommendations on good research practice [25].

In this article, we focus on the rice-growing households in the survey, defined as those that grew rice in both 2002 and 2008. For this reason, we have created a sub-panel of rice growers (referred to as 'the panel'), comprising of 317 households interviewed in both 2002

\footnotetext{
${ }^{4}$ Cassava and maize are two of the most important crops in the five countries.

5 The Afrint I project (2002-2005) and the Afrint II project (2006-2008) $[23,24]$.
} 


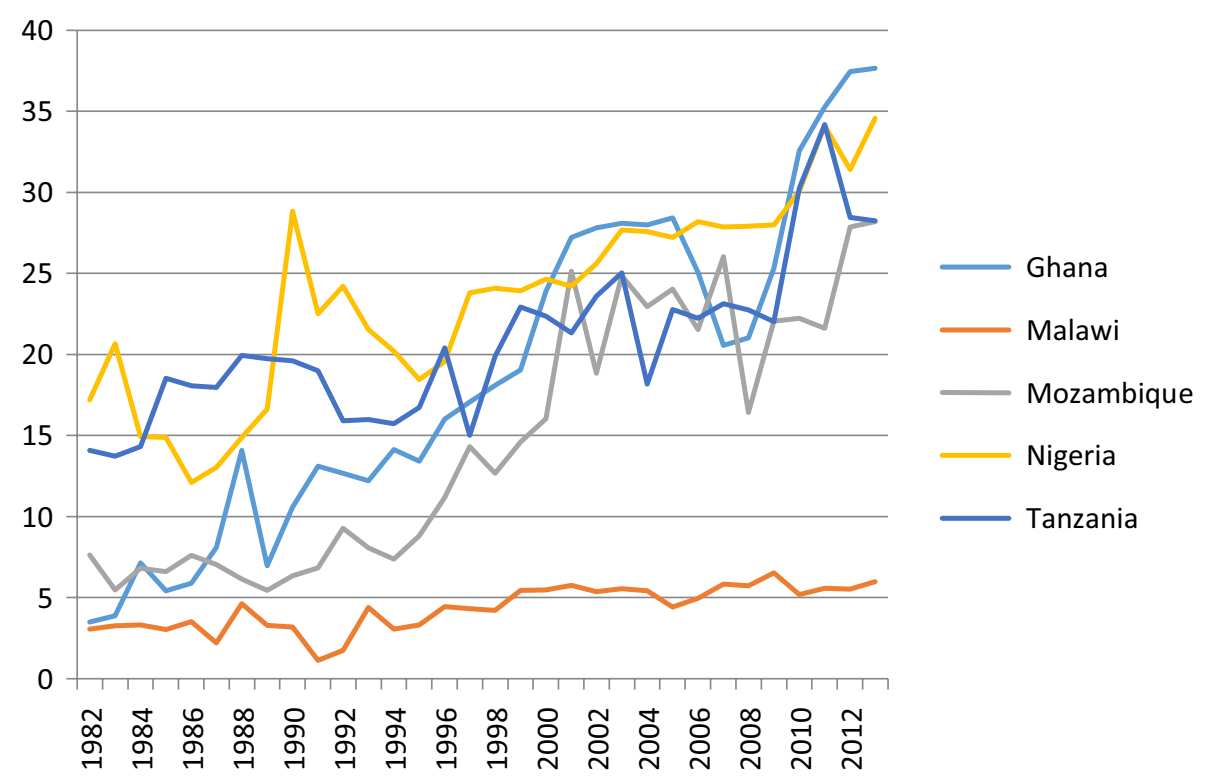

Fig. 1 Milled rice consumption per capita (kg) trends 1982-2013. Data source: [56]

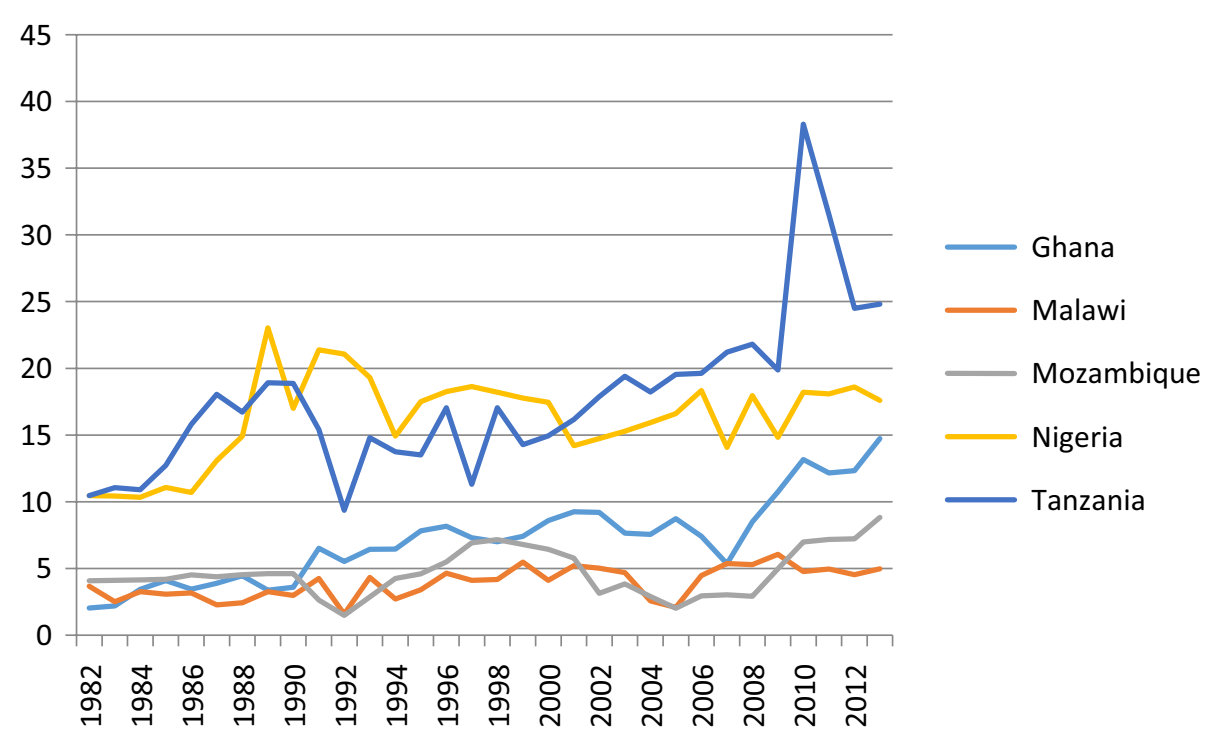

Fig. 2 Milled production per capita (kg) trends 1982-2013. Paddy rice was converted to its milled equivalent using a conversion ratio of 0.65 [see e.g. 6]. Data source: $[22,57]$

and 2008, and for whom retrospective data for the year of household formation (referred to as 'the reference year') are also available. Only five of the nine countries, Ghana, Malawi, Nigeria, Tanzania and Mozambique, are represented in this panel, since there were no surveyed households growing rice in the other countries. The rice grower panel covers households in 25 villages (see Table 1). Household-level data are complemented by village- and country-level data.

\section{Modelling strategy}

The modelling strategy aims to capture the drivers of production changes by using multilevel and longitudinal data. Here, both countries and villages have been sampled purposively. In the model, we treat the effects from the villages and from the countries as random effects to reflect the variability in the results obtained due to localization and/or regionalization We thereby represent these as a sample of possible effects (as well as show the variability 


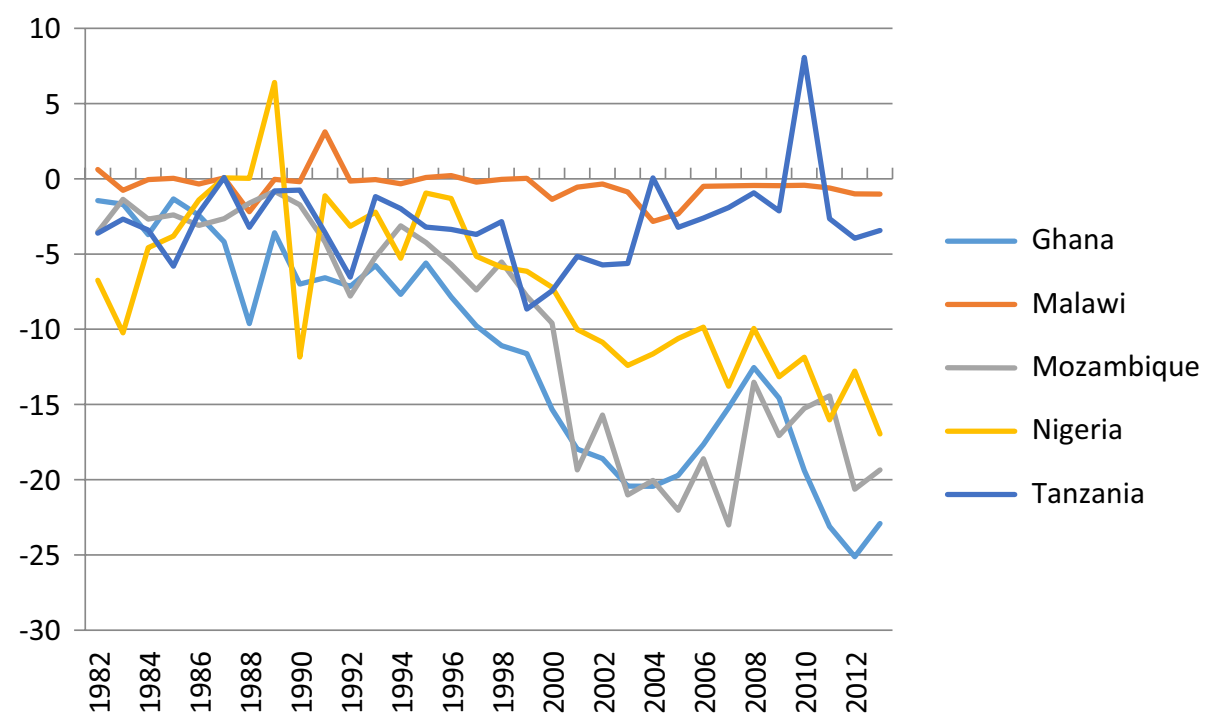

Fig. 3 Milled production — consumption balance (kg/per capita) trends 1982-2013. Paddy rice was converted to its milled equivalent using a conversion ratio of 0.65 [see e.g. 8]. Data source: $[22,56,57]$

Table 1 Distribution of households

\begin{tabular}{lccc}
\hline Country & Villages & \multicolumn{2}{l}{ Households } \\
\cline { 3 - 4 } & & Total & Percentage \\
\hline Ghana & 4 & 119 & 38 \\
Malawi & 2 & 48 & 15 \\
Nigeria & 9 & 34 & 11 \\
Tanzania & 5 & 98 & 31 \\
Mozambique & 5 & 18 & 6 \\
Total & 25 & 317 & 100 \\
\hline
\end{tabular}

in these), instead of pointing out the effects from the specific villages and countries. In the longitudinal data analysis, our data refer to three different time periods:

- reference year (for which the average was 1984) to $2002\left(t_{0}\right.$ to $t_{1}$; or period $\left.p_{1}\right)$

- 2002-2008 ( $t_{1}$ to $t_{2}$; or period $\left.p_{2}\right)$ and

- reference year to $2008\left(t_{0}\right.$ to $t_{2}$; or period $p_{1}+p_{2}$, also denoted $\left.p_{1+2}\right)$.

We model a characteristic of the individual household $i$ in village $j$ and country $k$ at time $t$ as an additive function of the possible effect of a number of explanatory variables. One such characteristic studied here is the logarithm of the amount of rice produced (in $\mathrm{kg}$ ) in the individual households at different time points; another is the logarithm of the relation between the amounts of rice produced at two different time points.

Table 2 presents an overview of the explanatory variables involved and the reasons for including them in the analysis. These range from macro-level variables, being estimates of the effects of national policies related to the individual countries, to the most important determinants of production at household level, including technological drivers of intensification and commercialization variables. To investigate the distributional consequences of production changes, two distributional dimension variables, viz. gender of farm manager and village elite membership, are considered at the household level. The farm manager was self-defined as the person in charge of making general decisions regarding the farm on a daily basis. We acknowledge the shortcoming in this definition, which assumes that only one person in the household decides over all the plots and crops on the farm, when in fact women and men may control different plots and crops. The definition is used due to the limitations of the present data set. ${ }^{6}$ Following Andersson et al. [28], we use total cultivated area as proxy for elite membership, ${ }^{7}$ while being aware of its limitations. We also include

\footnotetext{
${ }^{6}$ We are well aware of that it is more common in the literature to use the gender of the head of household in similar analyses. But also the headship typology contains biases, including the implicit assumption of a hierarchical and patriarchal system of household governance, often proven invalid when empirically investigated [see e.g. 26, 27]. In addition, this makes cross-survey comparisons difficult. Moreover, it should be noted that the incidence of manager-head of household correspondence is $86 \%$ in our survey, suggesting that the two overlap considerably.

7 The definition of elite membership varies slightly between the statistical models we use. In the third model, it is defined as "the upper decile of farms in the village with respect to their total cultivated area in 2002", while in the first two models this definition is expanded to include the requirement that the farms also had increased their cultivated area since the reference year. See the modelling subsections.
} 
Table 2 Overview of variables and associated assumptions

\begin{tabular}{|c|c|c|}
\hline Variable groups & Variables & Assumption for inclusion \\
\hline \multirow[t]{2}{*}{ Controls } & Age of farm under present management in 2002 (logged) & Production is expected to be curvilinear with respect to age $\mathrm{a}^{\mathrm{a}}$ \\
\hline & Descendant households & $\begin{array}{l}\text { Descendant households are expected to invest in higher } \\
\text { production than their predecessors }\end{array}$ \\
\hline Area & Area under rice, ha logged & $\begin{array}{l}\text { Growth in production is assumed to be largely extensive. Due } \\
\text { to diminishing returns, the correlation is expected to be } \\
\text { curvilinear }\end{array}$ \\
\hline \multirow[t]{5}{*}{ Improved variety } & Used improved variety in 2002 & $\begin{array}{l}\text { Use of improved variety is expected to increase production, } \\
\text { since improved varieties are higher yielding than traditional } \\
\text { varieties }\end{array}$ \\
\hline & Used improved variety in 2008 & \\
\hline & Used improved variety at both considered time points & \\
\hline & $\begin{array}{l}\text { Stopped using improved variety between the two considered } \\
\text { time points }\end{array}$ & \\
\hline & $\begin{array}{l}\text { Started using improved variety between the two considered } \\
\text { time points }\end{array}$ & \\
\hline \multirow[t]{3}{*}{ Land type } & Used lowland at both considered time points & $\begin{array}{l}\text { Use of lowland is expected to positively affect production, } \\
\text { since yields are expected to increase }\end{array}$ \\
\hline & $\begin{array}{l}\text { Stopped using lowland between the two considered time } \\
\text { points }\end{array}$ & \\
\hline & $\begin{array}{l}\text { Started using lowland between the two considered time } \\
\text { points }\end{array}$ & \\
\hline \multirow[t]{3}{*}{ Fertilizer } & Used fertilizer at both considered time points & $\begin{array}{l}\text { Use of seed fertilizer technology is expected to positively } \\
\text { affect production by increasing yields }\end{array}$ \\
\hline & $\begin{array}{l}\text { Decreased or stopped using fertilizer between the two con- } \\
\text { sidered time points }\end{array}$ & \\
\hline & $\begin{array}{l}\text { Started or increased using fertilizer between the two consid- } \\
\text { ered time points }\end{array}$ & \\
\hline \multirow[t]{3}{*}{ Tractor ploughing } & Used tractor plough at both considered time points & $\begin{array}{l}\text { Use of tractor ploughing is expected to positively affect } \\
\text { production by facilitating an area expansion (extensive } \\
\text { growth) }\end{array}$ \\
\hline & $\begin{array}{l}\text { Stopped using tractor plough between the two considered } \\
\text { time points }\end{array}$ & \\
\hline & $\begin{array}{l}\text { Started using tractor plough between the two considered } \\
\text { time points }\end{array}$ & \\
\hline \multirow[t]{3}{*}{ Commercialization } & Sold rice at both considered time points & $\begin{array}{l}\text { Sale of rice is expected to positively affect production, since } \\
\text { the availability of market outlets is expected to encourage } \\
\text { surplus production }\end{array}$ \\
\hline & $\begin{array}{l}\text { Stopped or decreased selling rice between the two consid- } \\
\text { ered time points }\end{array}$ & \\
\hline & $\begin{array}{l}\text { Started or increased selling rice between the two considered } \\
\text { time points }\end{array}$ & \\
\hline \multirow[t]{3}{*}{ Policy } & $\begin{array}{l}\text { Government expenditure on agriculture and rural develop- } \\
\text { ment during the period (lagged and logged) }\end{array}$ & $\begin{array}{l}\text { Increasing government expenditure is expected to positively } \\
\text { affect production by providing an enabling environment }\end{array}$ \\
\hline & $\begin{array}{l}\text { Import of rice in relation to gross domestic production during } \\
\text { the period (lagged and logged) }\end{array}$ & $\begin{array}{l}\text { Increased import dependence is expected to negatively } \\
\text { affect domestic production, since imported rice will drive } \\
\text { down local market prices and thereby undermine produc- } \\
\text { tion incentives }\end{array}$ \\
\hline & $\begin{array}{l}\text { Gross domestic product (GDP) per capita during the period } \\
\text { (lagged and logged) }\end{array}$ & $\begin{array}{l}\text { We assume a high elasticity of rice production to economic } \\
\text { growth }\end{array}$ \\
\hline \multirow[t]{2}{*}{ Distributional dimensions } & Proxy for village elite membership & $\begin{array}{l}\text { Smallholder-friendly development would decrease the } \\
\text { importance of elite membership }\end{array}$ \\
\hline & Gender of farm manager in 2002 & $\begin{array}{l}\text { Discrimination of women is expected to negatively affect } \\
\text { production }\end{array}$ \\
\hline \multirow[t]{2}{*}{ Weather } & Drought in E and S. Africa in 2002, village dummy & Control for and estimate of the effects of drought \\
\hline & Floods in W. Africa in 2008, village dummy & Control for and estimate of the effects of flood \\
\hline
\end{tabular}

\footnotetext{
a This effect is sometimes referred to as the Chayanov effect, after the Russian agricultural economist who was first to document it [58]
} 
household-specific control variables, namely age of farm under the present management in 2002 and whether the household has partitioned due to a generational shift during the period from 2002 to 2008. Finally, since extreme and unexpected weather events may severely affect the production performance, we also include two weather dependence control variables at the village level.

\section{Introduction to the rice grower panel}

The majority of panel households in this study, or $88 \%$, are male-headed, with female-headed households making up the remaining $12 \% .{ }^{8}$ The h)ead of household was almost invariably also the farm manager: $86 \%$ of the households had a male farm manager and $14 \%$ a female farm manager. In 2008, the average farm manager was 47 years old and had been to school for 5 years. The average household was made up of four members. In 2002, the mean age of the farm, i.e. the number of years it had been under its present management, was 18 years with a range from 2 to 75 years. Only a very small share (3\%) of the panel households consist of descendant households where the person who was the head of household in 2002 had deceased between the two rounds of data collection. Hence, the average age of the farms in the panel in 2008 is slightly lower than the 24 years that would have been the case if such partitioning of the original household had not occurred.

On average, a farm's total cultivated area was 2.3 ha in 2008, of which 0.89 ha was devoted to rice. Individual farms had in some cases changed size between 2002 and 2008 , and on average these farms had increased their cultivated area by 0.4 ha. Of the total number of farms, $7 \%$ had increased their total cultivated area since the reference year. As a proxy for elite membership, we use the upper decile of farms in the village with respect to their total cultivated area in 2002. In 2002, $12 \%$ of the total number of farms belonged to the elite membership group.

\section{Rice production performance across countries and villages in 2002 and 2008}

Table 3 shows that on average, panel households dedicated 0.89 ha of land to rice cultivation in 2008 compared to 0.76 ha in 2002, which represents an increase by $17 \%$. The overall rice production per household, however, remained almost constant during the period, only increasing by $20 \mathrm{~kg}$, or $2 \%$, from 1075 to $1095 \mathrm{~kg}$ on

\footnotetext{
8 Two categories of headship are defined: female and male. The label 'maleheaded household' indicates only that an adult man is physically present in the household. The label 'female-headed household' includes both de jure (households headed by unmarried, divorced or widowed women) and de facto (households headed by women in their husbands' absence, due to migration or other reasons). We have earlier recognized the shortcomings and biases in this typology (see note 6).
}

average, while rice yields declined by $12 \%$ between 2002 and 2008, from 1477 to $1296 \mathrm{~kg} / \mathrm{ha} .{ }^{9}$ These figures, however, obscure substantial spatial and temporal variation.

If we consider area and total production, it can, for instance, be noted that in Nigeria, households dedicated on average 2.46 ha to rice in 2008 and harvested over $3143 \mathrm{~kg}$, while in Mozambique the same year the corresponding figures were only 0.29 ha and $225 \mathrm{~kg}$. If we consider yields in 2008, these ranged from an average of $402 \mathrm{~kg} / \mathrm{ha}$ in Ghana to as much as $2237 \mathrm{~kg} / \mathrm{ha}$ in Malawi, with higher yields not appearing to only be linked to smaller plot sizes. Patterns over the 2002-2008 period also vary among the countries: in Mozambique, falling acreages coupled with increasing production resulted in a $253 \%$ yield increase. In Ghana, by contrast, a more extensive production pattern resulted in a $67 \%$ yield decrease.

Table 4 shows that there are also substantial variations between villages within countries in relation to production patterns over time. This suggests that the overall production increase observed for the panel as such, although minimal, is due to a mixed pattern of extensification and intensification. That the relative change in overall rice area was larger than the relative change in production reflects the fact that in many areas yields are falling, which is also reflected in the overall average yield decrease of $12 \%$.

When considering weather-related shocks, it can be noted that $34 \%$ of households were affected by the drought in Eastern and Southern Africa in 2002, while $7 \%$ were affected by the floods in West Africa in 2008.

Technology adoption, management and commercialization Table 5 shows that three-quarters of the households reported to be planting rice in lowland conditions in 2008, which is a somewhat lower share than in 2002. The table also suggests that there was greater upland-lowland mobility in rice production between 2002 and 2008 than between the reference year and 2002. This could in part be due to the new and high-yielding upland rice varieties developed by the Africa Rice Center and the International Rice Research Institute (IRRI), which have been successfully introduced in many countries in Africa over the past 10 years. This has made upland rice production a more productive and profitable enterprise than it used to be [30].

In relation to the adoption of improved varieties, we can also see a substantial increase. About $25 \%$ of farmers reported having started using such varieties between 2002 and 2008 and in total $42 \%$ of the respondents use

\footnotetext{
${ }^{9}$ Production figures for the panel tally well with those for the two cross sections from which the panel households were drawn, suggesting a low degree of panel bias [29].
} 


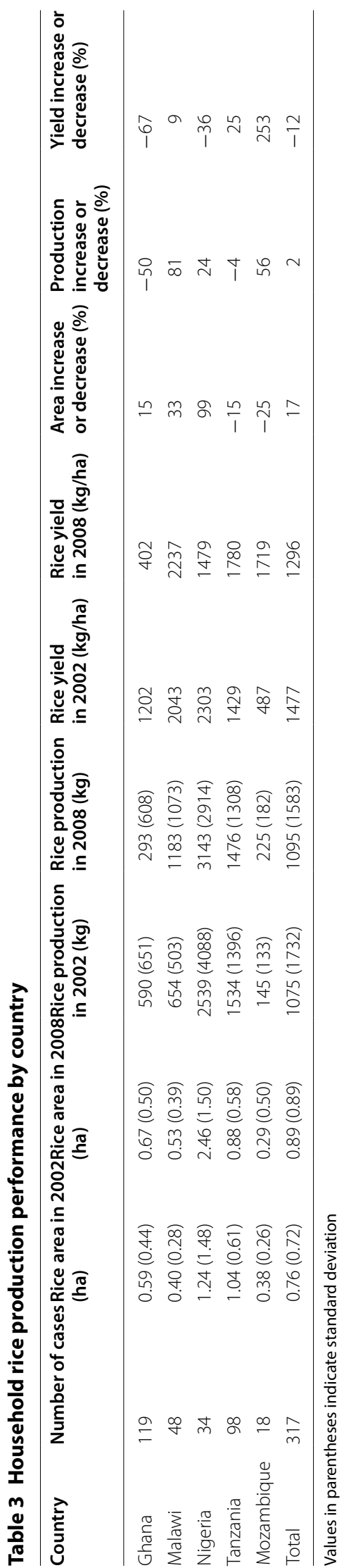




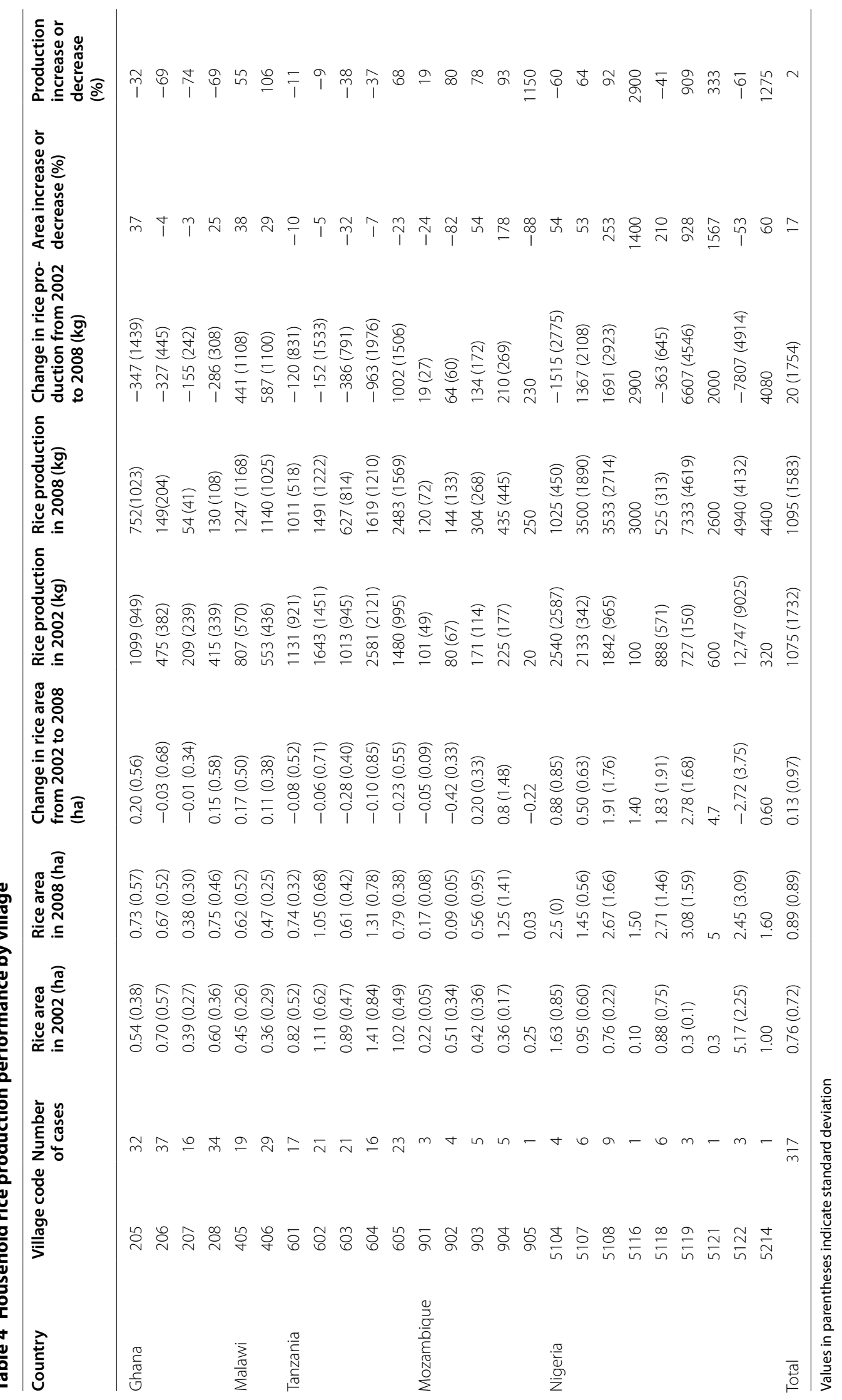


Table 5 Rice technology adoption, management and commercialization

\begin{tabular}{|c|c|c|c|c|c|c|}
\hline & Reference year (\%) & Reference year-2002 (\%) & $2002(\%)$ & Reference year-2008 (\%) & 2008 (\%) & $2002-2008(\%)$ \\
\hline Lowland use & $82(281)$ & & $82(317)$ & & $75(268)$ & \\
\hline Used lowland at both time points & & $70(317)$ & & $44(317)$ & & $51(317)$ \\
\hline $\begin{array}{l}\text { Stopped using lowland between } \\
\text { the two time points }\end{array}$ & & $2(317)$ & & $14(317)$ & & $16(317)$ \\
\hline $\begin{array}{l}\text { Started using lowland between the } \\
\text { two time points }\end{array}$ & & $1(317)$ & & $11(317)$ & & $12(317)$ \\
\hline Tractor ploughing & $14(277)$ & & $23(312)$ & & $23(310)$ & \\
\hline $\begin{array}{l}\text { Used tractor plough at both time } \\
\text { points }\end{array}$ & & $11(312)$ & & $9(310)$ & & $15(310)$ \\
\hline $\begin{array}{l}\text { Stopped using tractor plough } \\
\text { between the two time points }\end{array}$ & & $2(312)$ & & $4(310)$ & & $8(310)$ \\
\hline $\begin{array}{l}\text { Started using tractor plough } \\
\text { between the two time points }\end{array}$ & & $10(312)$ & & $11(310)$ & & $8(310)$ \\
\hline Fertilizer use & $30(274)$ & & $30(301)$ & & $42(256)$ & \\
\hline Used fertilizer at both time points & & $18(317)$ & & $18(317)$ & & $22(317)$ \\
\hline $\begin{array}{l}\text { Stopped using fertilizer between } \\
\text { the two time points }\end{array}$ & & $8(317)$ & & $6(317)$ & & $3(317)$ \\
\hline $\begin{array}{l}\text { Started using fertilizer between } \\
\text { the two time points }\end{array}$ & & $7(317)$ & & $12(317)$ & & $11(317)$ \\
\hline Improved rice variety use & $17(275)$ & & $24(307)$ & & $42(315)$ & \\
\hline $\begin{array}{l}\text { Used improved rice variety at } \\
\text { both time points }\end{array}$ & & $12(307)$ & & $12(315)$ & & $14(315)$ \\
\hline $\begin{array}{l}\text { Stopped using improved rice } \\
\text { variety between the two time } \\
\text { points }\end{array}$ & & $3(307)$ & & $3(315)$ & & $10(315)$ \\
\hline $\begin{array}{l}\text { Started using improved rice } \\
\text { variety between the two time } \\
\text { points }\end{array}$ & & $8(307)$ & & $25(315)$ & & $25(315)$ \\
\hline Commercialization (sold rice) & $48(308)$ & & $66(315)$ & & $61(314)$ & \\
\hline Sold rice at both time points & & $40(308)$ & & $36(314)$ & & $47(314)$ \\
\hline $\begin{array}{l}\text { Stopped to sell or decreased the } \\
\text { sale of rice between the two } \\
\text { time points }\end{array}$ & & $15(309)$ & & $12(317)$ & & $40(317)$ \\
\hline $\begin{array}{l}\text { Started to sell or increased the } \\
\text { sale of rice between the two } \\
\text { time points }\end{array}$ & & $51(309)$ & & $69(317)$ & & $37(317)$ \\
\hline
\end{tabular}

Values in parentheses indicate number of cases

improved varieties in 2008 compared to only $24 \%$ in 2002. But only $14 \%$ of households cultivated improved rice varieties in both 2002 and 2008. We can also see that only about $20 \%$ of the households have used fertilizer at both points in time, and that the use of fertilizer has become slightly more common over time. For ploughing by tractor, there are modest changes over time.

The commercialization variables, referring to whether a farmer is marketing some of the rice crop and whether $\mathrm{s} /$ he has entered or exited the rice market or changed sales volumes over time, show that while the majority of farmers sell rice, there has been a slight withdrawal from markets, from $66 \%$ in 2002 to $61 \%$ in 2008. Out of these farmers, as many as $47 \%$ reported that they had sold rice both in 2002 and in 2008. It can also be noted that mobility in and out of markets has increased over time: The share of households that stopped or reduced their sale of rice between 2002 and 2008 is similar to the share that started or increased the sale of rice during this time period. Over longer time periods, which span from the reference year to 2002 and from the reference year to 2008 , respectively, very few stopped or reduced their sales, suggesting that market exit was temporary.

\section{Macro-level conditions}

To capture the influence of government policy, three macro-level variables are specified in Table 6, disaggregated by country. As the table shows, government expenditure on agriculture and rural development as a share of total government expenditure varies significantly between the countries, even if some improvements over time can be noted in all countries but Tanzania, likely 
Table 6 Macro-level variables for models

\begin{tabular}{|c|c|c|c|c|c|}
\hline \multirow[t]{2}{*}{ Macro-level variables } & \multicolumn{5}{|l|}{ Mean } \\
\hline & Ghana & Malawi & Nigeria & Tanzania & Mozambique \\
\hline \multicolumn{6}{|l|}{ Government expenditure on agriculture and rural development ${ }^{a}$} \\
\hline Government expenditure on agriculture and rural development, 2002 (lagged by 3 years) (\%) & 3.50 & 6.24 & 1.62 & 3.9 & 1.2 \\
\hline Government expenditure on agriculture and rural development, 2008 (lagged by 3 years) (\%) & 8.8 & 17.2 & 4.8 & 3.0 & 9.0 \\
\hline Budget share allocations to agriculture ratio, 2008 over 2002 (lagged by 3 years) & 2.51 & 2.76 & 2.96 & 0.77 & 7.50 \\
\hline \multicolumn{6}{|l|}{ Imports of rice ${ }^{c}$} \\
\hline Imports of rice in relation to gross domestic production 1995-1999 (\%) & 40 & 2 & 25 & 14 & 54 \\
\hline Imports of rice in relation to gross domestic production, 2001-2005 (\%) & 105 & 6 & 67 & 11 & 140 \\
\hline Import of rice share ratio, 2001-2005 over 1995-1999 & 2.63 & 3.00 & 2.68 & 0.79 & 2.59 \\
\hline \multicolumn{6}{|l|}{ GDP per capita } \\
\hline GDP per capita 2001 (constant year 2000 USD value) & 259.8 & 138.4 & 368.7 & 275.9 & 254.7 \\
\hline GDP per capita 2007 (constant year 2000 USD value) & 314.2 & 154.5 & 473.4 & 347.2 & 350.7 \\
\hline GDP per capita ratio, 2007 over 2001 & 1.21 & 1.12 & 1.28 & 1.26 & 1.38 \\
\hline \multicolumn{6}{|c|}{$\begin{array}{l}\text { Source: authors' own calculations based on data from the International Monetary Fund (IMF), except the data for Tanzania which comes from the Government of } \\
\text { Tanzania }\end{array}$} \\
\hline \multicolumn{6}{|c|}{ a The data refer to 1999. We used lagged data to allow time for government policies to have impact on farmers' production and production decisions } \\
\hline \multicolumn{6}{|c|}{ b The data refer to 2003 for Nigeria, 2004 for Zambia and Ghana, 2005 for Tanzania and 2006 for Malawi } \\
\hline \multicolumn{6}{|l|}{ c The figures on imports refer to 5-year averages } \\
\hline \multicolumn{6}{|c|}{$\begin{array}{l}{ }^{d} \text { The reason we report on 'imports of rice in relation to gross domestic production' (i.e. imports divided by gross domestic production) instead of the more common } \\
\text { variable used in relation to reporting on imports, namely 'imports of rice as share of domestic consumption' (i.e. imports divided by gross domestic production plus/ } \\
\text { and imports), is that the former is more appropriate in relation to the statistical modelling we shall carry out }\end{array}$} \\
\hline e The figures refer to 2001 and 2007, respectively, at constant 2000 USD PPP values & & & & & \\
\hline
\end{tabular}

reflecting a more conducive policy environment following the 2003 Maputo declaration. In 2008, only Malawi surpassed the $10 \%$ share of public spending on rural development agreed to in this declaration. However, the explanation for the relatively high expenditure share in Malawi is principally due to the agricultural input subsidy programmes run in the country [31]. While Ghana and Mozambique were close to reaching the Maputo target, the share of government expenditure devoted to rural development was still considerably lower than in Malawi. The variable that we use to trace economic growth and development in general, i.e. gross domestic product (GDP) per capita, has improved over time in all countries.

Finally, we consider rice imports. Table 6 (see also Fig. 3) shows that Malawi and Tanzania are almost selfsufficient in rice. For Malawi, this is probably due to the low share that rice constitutes in national diets, together with the fact that, as pointed out by Demont [10], it is a landlocked country, which makes large-scale rice imports prohibitively expensive. For Tanzania, consumer preferences are geared heavily towards local rice varieties, explaining the relatively low share of imports [10]. In contrast, the remaining three countries are increasingly dependent on rice imports. Although consumers are known to prefer local rice varieties in Mozambique, this is the country where import of rice in relation to gross domestic production is the highest [10]. This paradox shows the inability of domestic production-which in the case of Mozambique is still very small-to keep up with increasing consumer demand for rice. In Nigeria and Ghana, by contrast, Demont [10] reports dominant consumer preferences for imported rice varieties, likely explaining the dependence on imports in these countries. Nigeria, as the second largest importer of rice in the world, spends $\$ 1.56-2.2$ billion per year on rice imports [32]. Moreover, it seems that in countries where consumers have already acquired a taste for imported rice it is difficult to reverse this trend, not the least because imported rice has established quality standards against which local rice (particularly, due to poor post-harvesting and milling practices) fails to compete [10]. Hence, it is of little surprise that the table shows that countries starting off with a big import share are even more import dependent today, by around 2.5 times so. Efforts to alter this have proven difficult. For instance, Nigeria initiated a rice transformation agenda in 2011 aiming for rice selfsufficiency [33]. Inter alia, the government announced that it was planning to ban rice imports from late 2015 to effectively end the country's extreme dependence on rice imports [34], suggesting that Nigerian rice farmers could soon face a totally restructured market for their produce. As a first step, a $110 \%$ duty on rice imports was introduced in January 2013 to encourage local rice production, 
although it did not have the desired effect as informal cross border trade rather than local production boomed $[34,35]$. In 2014, a revised rice sector policy lowered the import duty to between 30 and $70 \%$ up to 2017 in what appears to be an attempt to discourage smuggling and make investments in the rice sub-sector more profitable again [32, 35-37]. But as the ambitious target of achieving self-sufficiency together with the introduction of an import ban is approaching, it can be noted that Nigeria is projected to produce less rice in 2015 than it did in 2014, while imports are projected to reach a record 3.5 million tons, or up $17 \%$ from 2014 [38].

\section{Modelling production for the period $p_{1}$ (reference year to 2002) ${ }^{10}$}

The first model we consider, model 1 , deals with the period from the reference year $\left(t_{0}\right)$ to $2002\left(t_{1}\right)$, i.e. period $p_{1}$. Model 1 is defined as a production function where $\ln \left(P_{i j k t_{1}}\right)$ is the logged production of rice (in $\mathrm{kg}$ ) of household $i$ in village $j$ and country $k$ at time $t_{1}{ }^{11}$ The logged production, $\ln \left(P_{i j k t_{1}}\right)$, is a function of a number of explanatory variables that refer to circumstances either at the reference year (time $t_{0}$ ), at the year 2002 (time $t_{1}$ ), or during the period from the reference year to $2002\left(\right.$ period $\left.p_{1}\right)$ (N.B. $t_{1}(L)$ indicates variables referring to lagged values with respect to $\left.t_{1}\right)$.

Model 1 is specified as follows:

$$
\begin{aligned}
\ln \left(P_{i j k t_{1}}\right)= & \delta_{k t_{1}}+\gamma_{j k t_{1}}+\text { Farmage }_{i j k t_{1}} \beta_{1 t_{1}}+\mathrm{DH}_{i j k} \beta_{2 t_{1}} \\
& +\operatorname{Area}_{i j k t_{1}} \beta_{3 t_{1}}+\operatorname{IRV}_{i j k t_{1}} \beta_{4 t_{1}} \\
& +\operatorname{AULL}_{i j k p_{1}} \beta_{5 t_{1}}+\operatorname{StoppedULL}_{i j k p_{1}} \beta_{6 t_{1}} \\
& + \text { StartedULL }_{i j k p_{1}} \beta_{7 t_{1}}+\operatorname{AUF}_{i j k p_{1}} \beta_{8 t_{1}} \\
& +\operatorname{StoppedUF}_{i j k p_{1}} \beta_{9 t_{1}}+\operatorname{StartedUF}_{i j k p_{1}} \beta_{10 t_{1}} \\
& +\operatorname{AUP}_{i j k p_{1}} \beta_{11 t_{1}}+\operatorname{StoppedUP}_{i j k p_{1}} \beta_{12 t_{1}} \\
& +\operatorname{StartedUP}_{i j k p_{1}} \beta_{13 t_{1}}+\operatorname{ASellingR}_{i j k p_{1}} \beta_{14 t_{1}} \\
& + \text { StoppedSellingR }_{i j k p_{1}} \beta_{15 t_{1}} \\
& +\operatorname{StartedSellingR}_{i j k p_{1}} \beta_{16 t_{1}}+\operatorname{FarmS}_{i j k} \beta_{17 t_{1}} \\
& +\operatorname{Gender}_{i j k} \beta_{18 t_{1}}+\operatorname{Drought}_{j k t_{1}} \beta_{19 t_{1}} \\
& +\operatorname{SGBudget}_{k t_{1}(L)} \beta_{20 t_{1}}+\operatorname{ImportR}_{k t_{1}(L)} \beta_{21 t_{1}} \\
& +\operatorname{GDP}_{k t_{1}(L)} \beta_{22 t_{1}}+\mathrm{u}_{i j k t_{1}}
\end{aligned}
$$

\footnotetext{
${ }^{10}$ For 16 of the households in the panel the production of rice was zero at some point(s). These households have been excluded in the modelling to avoid numerical problems. This was the case for eight households in three Ghanaian villages in 2008, five households in two Malawian villages in 2002, one household in Malawi in 2008 and three households in two Tanzanian villages in 2002. The reasons for these crop failures have not been investigated, but in the case of Ghana we infer that the flooding in 2008 destroyed the crop of the households that experienced a crop failure there.

11 Subscript $i$ ranges over the 317 different households, $j$ ranges over the 22 villages and $k$ ranges over the five countries.
}

where variables and notations (with suppressed subscripts when clarity is not standing the risk of being lost) are as described below:

$\ln (\mathrm{P}) \quad$ logarithm of rice production (in $\mathrm{kg}$ )

Farmage age of the farm under the present management in 2002 (logged number of years)

DH dummy variable for descendant household

Area logarithm of area under rice (in ha)

IRV dummy variable for the use of improved variety

AULL dummy variable for having used lowland at both time points

StoppedULL dummy variable for having stopped using lowland

StartedULL dummy variable for having started using lowland

AUF dummy variable for having used fertilizer at both time points

StoppedUF dummy variable for having stopped using fertilizer

StartedUF dummy variable for having started using fertilizer

AUP dummy variable for having used tractor plough at both time points

StoppedUP dummy variable for having stopped using tractor plough

StartedUP dummy variable for having started using tractor plough

AsellingR dummy variable for having sold rice at both time points

StoppedsellingR dummy variable for having stopped or decreased selling of rice

StartedsellingR dummy variable for having started or increased selling of rice

FarmS dummy proxy variable for elite membership (i.e. among the upper decile of farms in the village with respect to their total cultivated area in 2002 and that had increased their cultivated area since the reference year) ${ }^{12}$

Gender gender of farm manager in 2002

Drought $_{j k t_{1}} \quad$ dummy variable for drought in E and S. Africa, for village $j$ in country $k$ at time $t_{1}$ SGBudget $_{k t_{1}(L)}$ logarithm of government expenditure share on agriculture and rural development in country $k$ at time $t_{l}$, lagged by 3 years (i.e. in 1999)

\footnotetext{
${ }^{12}$ Due to multicollinearity between total cultivated area and elite membership in the sample data, we have only included elite membership in the models.
} 
$\operatorname{ImportR}_{k t_{1}(L)}$

logarithm of import of rice in relation to gross domestic production in country $k$ at time $t_{1}$, 5-year average, lagged by 3 years (i.e. 1995-1999)

$\mathrm{GDP}_{k t_{1}(L)}$ logarithm of GDP per capita in country $k$ at time $t_{1}$ lagged by 1 year (i.e. 2001) (constant year 2000 USD)

Finally, $\delta_{k t_{1}}$ is a latent characteristic (variable) for country $k$ (a random intercept) at time $t_{1} ; \gamma_{j k t_{1}}$ is a random factor for village $j$ in country $k$ at time $t_{1}$; and $u_{i j k t_{1}}$ is a residual, a random factor at the household level, i.e. for household $i$ in village $j$ and country $k$ at time $t_{1}$.

Considering the $\beta$ coefficients, we can use the $\beta_{3 t_{1}}$ coefficient to exemplify how these coefficients should be interpreted: By taking logged value of area, the $\beta_{3 t_{1}}$ coefficient will directly reflect the scale effect of relative change of production with respect to relative change in area at time $t_{1}$. The interpretation of $\beta$ coefficients for dummy variables is also straightforward, since the antilog of the $\beta$ value (i.e. $\exp (\beta))$ indicates the percentage change in production between households having the value of 1 for the dummy, as compared to those having the value 0 .

\section{Modelling production for period $p_{1+2}$ (reference year to 2008)}

The second model, model 2 , is also a production function, referring to the period from the reference year $\left(t_{0}\right)$ to $2008\left(t_{2}\right)$ where $\ln \left(P_{i j k t_{2}}\right)$ denotes the logged rice production of household $i$ in village $j$ and country $k$ at time $t_{2}$. Model 2 reconsiders the role of the explanatory variables as explanation of production of rice by covering a longer time period $\left(p_{1+2}\right)$. Hence, this second model replicates the results of the first model and thereby provides an indication of robustness and reliability of the models. Moreover, changes in regression coefficients may also be significant in terms of our assumptions.

Model 2 is specified as follows:
The variables are all defined as before, when not considering the subscripts specifying the spatial and temporal aspects. As the subscripts in the model above show, the following variables (here with suppressed subscripts) refer to the same time period $t_{1}$ as in the first model: Farmage, DH, FarmS and Gender; the following refer to time $t_{2}$ : Area and IRV; the following refer to time $t_{2}(L)$ (i.e. time $t_{2}$ with lagged values): SGBudget, ImportR and GDP; ${ }^{13}$ and the following refer to the behaviour over the longer time period from the reference year to 2008, period $p_{1+2}$ : AULL, StoppedULL, StartedULL, AUF, StoppedUF, StartedUF, AUP, StoppedUP, StartedUP, AsellingR, StoppedsellingR and StartedsellingR. One new variable is introduced, namely:Floods ${ }_{j k t 2}$ dummy variable for floods in W. Africa, for village $j$ in country $k$ at time $t_{2}$.

Again, $\delta_{k t_{2}}, \gamma_{j k t_{2}}$ and $u_{i j k t_{2}}$ refer to random factors on the respective levels of the country, village and household, but at time $t_{2}$. Also the interpretation of $\beta$ coefficients follows the same logic as in model 1 , but here referring to time $t_{2}$.

\section{Modelling changes in production}

In the third model (model 3), the variable under study is the change in production represented by the logged ratio of production of rice in 2008 over production in 2002 . By using panel data and a reduced form model as per Glewwe and Hall [39], this model was developed to identify the drivers behind changes in production through the combination of two separate models for the two panel rounds 2002 and 2008, respectively, and one model for the change in production between 2002 and 2008.

Also here, explanatory variables refer to either a state in 2002 (time $t_{1}$ ) (alternatively to the reference year $t_{0}$ ), or to the period from 2002 to 2008 (period $\left.p_{2}\right)$. The influence from the explanatory variables on production at the various points in time may be different. This is then reflected in different $\beta$ coefficients in the models at the two points in time. $\Delta \beta$ denotes

$$
\begin{aligned}
\ln \left(P_{i j k t_{2}}\right)= & \delta_{k t_{2}}+\gamma_{j k t_{2}}+\text { Farmage }_{i j k t_{1}} \beta_{1 t_{2}}+\mathrm{DH}_{i j k} \beta_{2 t_{2}}+\operatorname{Area}_{i j k t_{2}} \beta_{3 t_{2}}+\operatorname{IRV}_{i j k t_{2}} \beta_{4 t_{2}} \\
& +\operatorname{AULL}_{i j k\left(p_{1}+p_{2}\right)} \beta_{5 t_{2}}+\operatorname{StoppedULL}_{i j k\left(p_{1}+p_{2}\right)} \beta_{6 t_{2}}+\operatorname{StartedULL}_{i j k\left(p_{1}+p_{2}\right)} \beta_{7 t_{2}} \\
& +\operatorname{AUF}_{i j k\left(p_{1}+p_{2}\right)} \beta_{8 t_{2}}+\operatorname{StoppedUF}_{i j k\left(p_{1}+p_{2}\right)} \beta_{9 t_{2}}+\operatorname{StartedUF}_{i j k\left(p_{1}+p_{2}\right)} \beta_{10 t_{2}} \\
& +\operatorname{AUP}_{i j k\left(p_{1}+p_{2}\right)} \beta_{11 t_{2}}+\operatorname{StoppedUP}_{i j k\left(p_{1}+p_{2}\right)} \beta_{12 t 2}+\operatorname{StartedUP}_{i j k\left(p_{1}+p_{2}\right)} \beta_{13 t_{2}} \\
& +\operatorname{AsellingR}_{i j k\left(p_{1}+p_{2}\right)} \beta_{14 t_{2}}+\operatorname{StoppedSellingR}_{i j k\left(p_{1}+p_{2}\right)} \beta_{15 t_{2}} \\
& +\operatorname{StartedSellingR}_{i j k\left(p_{1}+p_{2}\right)} \beta_{16 t_{1}}+\operatorname{FarmS}_{i j k} \beta_{17 t_{2}} \\
& +\operatorname{Gender}_{i j k} \beta_{18 t_{2}}+\operatorname{Floods}_{j k t_{2}} \beta_{19 t_{2}} \\
& +\operatorname{SGBudget}_{k t_{2}(L)} \beta_{20 t_{2}}+\operatorname{ImportR}_{k t_{2}(L)} \beta_{21 t_{2}} \\
& +\operatorname{GDP}_{k t_{2}(L)} \beta_{22 t_{2}}+\mathrm{u}_{i j k t_{2}} .
\end{aligned}
$$


the change in the $\beta$ coefficient between $2008\left(t_{2}\right)$ and $2002\left(t_{1}\right)$ (i.e. $\left.\beta_{t_{2}}-\beta_{t_{1}}\right)$. Such a change in the influence from an explanatory variable can be estimated from a model of the logarithm of the ratio between production at the two time points (or equivalent: the difference of the logarithm of the production at the two time points) as seen by subtracting model 1 from model 2.

Changes in production between the two points in time may also result from changes occurring in the explanatory variables during the same time period. Especially, the macro-level variables have been subject to major changes between the two points in time, and we will therefore model the effects of these on changes in production levels.

Model 3 is specified as follows:

$$
\begin{aligned}
\ln \left(\frac{P_{i j k t_{2}}}{P_{i j k t_{1}}}\right)= & \left(\delta_{k t_{2}}-\delta_{k t_{1}}\right)+\left(\gamma_{j k t_{2}}-\gamma_{j k t_{1}}\right) \\
& + \text { Farmage }_{i j k t_{1}} \Delta \beta_{1}+\mathrm{DH}_{i j k} \Delta \beta_{2} \\
& +\Delta \operatorname{Area}_{i j k p_{2}} \beta_{3}+\operatorname{AUIRV}_{i j k p_{2}} \Delta 4 a \\
& + \text { StoppedUIRV }_{i j k p_{2}} \Delta_{4 b} \\
& + \text { StartedUIRV }_{i j k p_{2}} \Delta 4 c+\operatorname{AULL}_{i j k p_{2}} \Delta \beta_{5} \\
& + \text { StoppedULL }_{i j k p_{2}} \Delta \beta_{6}+\operatorname{StartedULL}_{i j k p_{2}} \Delta \beta_{7} \\
& +\operatorname{AUF}_{i j k p_{2}} \Delta \beta_{8}+\operatorname{StoppedUF}_{i j k p 2} \Delta \beta_{9} \\
& + \text { StartedUF }_{i j k p_{2}} \Delta \beta_{10}+\operatorname{AUP}_{i j k p_{2}} \Delta \beta_{11} \\
& +\operatorname{StoppedUP}_{i j k p_{2}} \Delta \beta_{12}+\operatorname{StartedUP}_{i j k p_{2}} \Delta \beta_{13} \\
& +\operatorname{ASellingR}_{i j k p_{2}} \Delta \beta_{14}+\operatorname{StoppedSellingR}_{i j k p_{2}} \Delta \beta_{15} \\
& +\operatorname{StartedSellingR~}_{i j k p_{2}} \Delta \beta_{16}+\operatorname{FarmS}_{i j k} \Delta \beta_{17} \\
& +\operatorname{Gender}_{i j k} \Delta \beta_{18}+\Delta \operatorname{SGBudget}_{k} \beta_{20} \\
& +\Delta \operatorname{ImportR}_{k} \beta_{21}+\Delta \operatorname{GDP}_{k} \beta_{22} \\
& \left.+ \text { u }_{i j k t_{2}}-\mathrm{u}_{i j k t_{1}}\right)
\end{aligned}
$$

Again, Farmage, DH, and Gender (with suppressed subscripts) are defined as before. $\Delta$ Area $_{i j k p 2}$ refers to the change in logarithm of rice area of the household $i$ in village $j$ and country $k$ during time period $p_{2}$. The specific use of improved rice varieties during period $p_{2}$ is described by introducing three new dummy variables (here with suppressed subscripts):

$\begin{array}{ll}\text { AUIRV } & \begin{array}{l}\text { dummy variable used for improved rice } \\ \text { variety at both time points } \\ \text { dummy variable for having stopped } \\ \text { using improved rice variety } \\ \text { dummy variable for having started using } \\ \text { improved variety }\end{array}\end{array}$

Elite membership is here (with suppressed subscripts) defined as:
FarmS dummy proxy variable for elite membership (i.e. among the upper decile of farms in the village with respect to their total cultivated area in 2002).

The variables AULL, StoppedULL, StartedULL, AUF, StoppedUF, StartedUF, AUP, StoppedUP, StartedUP, AsellingR, StoppedsellingR and StartedsellingR, all with subscripts $i j, k$, all refer to household $i$ in village $j$ and country $k$ during period $p_{2}$.

The macro-variable changes are: $\Delta$ SGBudget $_{k}$ (change in logarithm of budget allocations to agriculture in country $k$ between 1999 and 2005), $\Delta$ ImportR $_{\mathrm{k}}$ [change in logarithm of import of rice in relation to gross domestic production in country $k$ between the two lagged fiveyear time periods (1995-99 and 2001-05)] and $\Delta \mathrm{GDP}_{\mathrm{k}}$ (change in logarithm of GDP in country $k$ from 2001 to 2007).

The latent variables that are constant over time will be eliminated through the formation of differences of log production. Likewise, latent household effects that are variable over time will contribute to the difference of $\log$ production as an effect from the difference of values of the latent variable. Hence, any systematic effect (the time-averaged effect) will be removed from the difference of log production and the remaining is only the variation in this effect, i.e. $u_{i j k t_{2}}-u_{i j k t_{1}}$. The same applies to the latent effects on country level, $\Delta \delta_{k}=\delta_{k t_{2}}-\delta_{k t_{1}}$, as well as on village level, $\Delta \gamma_{j k}=\gamma_{j k t_{2}}-\gamma_{j k t_{1}}$; only the difference between the effects in time between $t_{1}$ (2002) and $t_{2}$ (2008) contribute to the model. The particular effect of ageing (in time) is captured in the Farmage and $\mathrm{DH}$ variables. In this third model, the $\beta$ coefficients reflect elasticities of production. Hence the $\beta_{3}$ parameter, for instance, reflects the elasticity of production with respect to area, with values over unity reflecting intensification, i.e. increased production stemming from increased yields, while values below unity by contrast reflect extensification, i.e. expanded area with lower than expected proportional correspondence in yield.

One should note that even if model 3 shows similarities to what would have been the case if subtracting model 1 from model 2, model 3 is not the equivalent of the latter, since model 3 models the effects of changes in some of the explanatory variables, while for other variables it models the effect of changes in the coefficients.

The analysis of the data in all three models has been carried out through 'mixed models' using the statistical software program IBM SPSS Statistics 20. Furthermore, we have carried out the same analysis by using MLwiN program (developed especially for multilevel modelling). However, the results were similar to the SPSS results. Therefore, the presented results described below are from the SPSS program. 


\section{Results and discussion} Household control variables

As suggested by Table 7, the household control variables are not significant in any of the models. This means that neither the number of years the farm has been under its current management nor whether there has been a generational shift has any significant effects on production. As can be expected, the cultivated area is one of the most important determinants of production in all three models. Model 1 shows that that an increase in cultivated

Table 7 Modelling rice production and production change over time

\begin{tabular}{|c|c|c|c|c|c|c|c|c|c|c|}
\hline \multirow[t]{4}{*}{ Variable groups } & \multirow[t]{4}{*}{ Variables } & \multicolumn{6}{|c|}{ Production models } & \multirow{3}{*}{\multicolumn{3}{|c|}{$\begin{array}{l}\text { Production change } \\
\text { model } \\
\text { Model } 3 \\
\text { Period } 2\left(p_{2}\right): t_{1} \text { to } t_{2}\end{array}$}} \\
\hline & & \multirow{2}{*}{\multicolumn{3}{|c|}{$\frac{\text { Model } 1}{\text { Period } 1\left(p_{1}\right): t_{0} \text { to } t_{1}}$}} & \multirow{2}{*}{\multicolumn{3}{|c|}{$\begin{array}{l}\text { Model } 2 \\
\text { Period } 1+2\left(p_{1+2}\right): t_{0} \\
\text { to } t_{2}\end{array}$}} & & & \\
\hline & & & & & & & & & & \\
\hline & & B & Std. Error & Sig. & B & Std. Error & Sig. & B & Std. Error & Sig. \\
\hline & (Constant) & -2.83 & 3.33 & & -34.89 & 33.08 & & 1.04 & 1.77 & \\
\hline \multirow[t]{2}{*}{ Controls } & $\begin{array}{l}\text { Age of farm under present management in } \\
2002 \text {, logged }\end{array}$ & 0.03 & 0.05 & & -0.05 & 0.06 & & -0.03 & 0.07 & \\
\hline & Descendant households, dummy & -0.45 & 0.24 & & 0.34 & 0.30 & & 0.45 & 0.34 & \\
\hline Area & Area under rice, logged (ha) & 0.63 & 0.06 & $* * *$ & 0.68 & 0.08 & $* * *$ & 0.49 & 0.07 & *** \\
\hline \multirow[t]{5}{*}{ Rice variety } & Used improved variety in 2002, dummy & -0.01 & 0.11 & & & & & & & \\
\hline & Used improved variety in 2008 , dummy & & & & 0.01 & 0.13 & & & & \\
\hline & $\begin{array}{l}\text { Always used improved rice variety during the } \\
\text { period }\end{array}$ & & & & & & & 0.12 & 0.21 & \\
\hline & $\begin{array}{l}\text { Stopped using improved rice variety during } \\
\text { the period }\end{array}$ & & & & & & & 0.36 & 0.20 & \\
\hline & $\begin{array}{l}\text { Started using improved rice variety during } \\
\text { the period }\end{array}$ & & & & & & & 0.01 & 0.15 & \\
\hline \multirow[t]{3}{*}{ Land type } & Always used lowland during the period & 0.02 & 0.11 & & -0.07 & 0.13 & & -0.08 & 0.16 & \\
\hline & Stopped using lowland during the period & 0.35 & 0.28 & & 0.01 & 0.17 & & 0.01 & 0.19 & \\
\hline & Started using lowland during the period & -0.41 & 0.33 & & -0.12 & 0.19 & & 0.01 & 0.22 & \\
\hline \multirow[t]{3}{*}{ Fertilizer } & Always used fertilizer during the period & 0.49 & 0.14 & $* * *$ & -0.28 & 0.18 & & -0.31 & 0.20 & \\
\hline & Stopped using fertilizer during the period & -0.03 & 0.16 & & -0.06 & 0.22 & & -0.44 & 0.32 & \\
\hline & Started using fertilizer during the period & 0.48 & 0.17 & ** & 0.08 & 0.17 & & 0.13 & 0.18 & \\
\hline \multirow[t]{3}{*}{ Ploughing } & Always used plough during the period & 0.41 & 0.16 & * & 0.39 & 0.21 & & 0.23 & 0.20 & \\
\hline & Stopped using plough during the period & 0.07 & 0.32 & & 0.30 & 0.25 & & -0.28 & 0.21 & \\
\hline & Started using plough during the period & 0.03 & 0.15 & & 0.31 & 0.17 & & 0.23 & 0.21 & \\
\hline \multirow[t]{3}{*}{ Commercialization } & Always sold rice during the period & 0.45 & 0.09 & $* * *$ & 0.48 & 0.12 & $* * *$ & 0.40 & 0.13 & ** \\
\hline & $\begin{array}{l}\text { Stopped or decreased selling rice during the } \\
\text { period }\end{array}$ & 0.03 & 0.14 & & 0.12 & 0.20 & & -0.82 & 0.16 & *** \\
\hline & $\begin{array}{l}\text { Started or increased selling rice during the } \\
\text { period }\end{array}$ & 0.37 & 0.10 & $* * *$ & 0.39 & 0.15 & * & 0.48 & 0.18 & ** \\
\hline \multirow[t]{3}{*}{ Macro-level variables } & $\begin{array}{l}\text { Share of state budget for agriculture during } \\
\text { the period, logged }\end{array}$ & 0.25 & 0.22 & & 2.57 & 2.28 & & 1.99 & 1.20 & \\
\hline & $\begin{array}{l}\text { Import of rice in relation to gross domestic } \\
\text { production during the period, logged }\end{array}$ & -0.43 & 0.17 & * & -1.33 & 0.94 & & -2.50 & 1.67 & \\
\hline & GDP per capita during the period, logged & 1.45 & 0.54 & ** & 6.08 & 4.86 & & -5.09 & 7.49 & \\
\hline \multirow[t]{2}{*}{ Distributional dimensions } & Elite membership, dummy & 0.36 & 0.17 & * & 0.04 & 0.20 & & 0.01 & 0.17 & \\
\hline & Gender of farm manager in 2002, dummy & -0.02 & 0.11 & & -0.12 & 0.14 & & 0.07 & 0.15 & \\
\hline \multirow[t]{2}{*}{ Weather } & $\begin{array}{l}\text { Drought in Eastern and Southern Africa 2002, } \\
\text { dummy }\end{array}$ & -0.35 & 0.24 & & & & & & & \\
\hline & Floods in West Africa 2008, dummy & & & & -0.89 & 0.43 & * & & & \\
\hline \multirow[t]{2}{*}{ Model info } & No. of cases & 284 & & & 297 & & & 297 & & \\
\hline & Missing (\%) & 10 & & & 6 & & & 6 & & \\
\hline
\end{tabular}

${ }^{*},{ }^{* *}$ and ${ }^{* * *}$ To denote test results significant at 5,1 and $0.1 \%$ levels 
area of $100 \%$ in the first period $\left(p_{1}\right)$ would result in a relative increase in production of $63 \%$ on average. The effect in model 2, covering the longer period from the reference year to $2008\left(p_{1+2}\right)$, is slightly bigger, and in model 3 , related to production change in period $\left(p_{2}\right)$, it is slightly smaller. These results indicate that about half of the change in area will be carried over to the change of production.

Whether farmers plant rice in upland or lowland conditions does not seem to affect production results. This picture is consistent in all three models: the production outcome for those who grew rice in lowland conditions both in 2002 and 2008 did not differ significantly from the results in rain-fed uplands. Similarly, the level of production of farmers who planted lowland rice at both points in time did not differ from those households that either stopped or entered this type of production during the same period. This is somewhat surprising, given that paddy varieties are usually higher yielding than upland varieties [40]. The fact that a majority of the households that grew rice in lowland conditions did not use irrigation could shed some light on this issue, since lowland varieties perform best under irrigated conditions. Moreover, with the more recently developed high-yielding upland rice varieties, the differences between upland and lowland conditions may have been somewhat reduced [30].

\section{Farm technology indicators}

The effects of the farm technology indicators, namely improved seed, fertilizer and ploughing varied ${ }^{14}$. For all three models, the use of improved rice varieties did not significantly affect production. There could be various reasons for this. The farmers may not be able to distinguish effectively between improved varieties and traditional, ${ }^{15}$ undermining the reliability of the variable as such. This has been reported in relation to for instance pigeon peas in Tanzania [41] and wheat in Pakistan [42]. Moreover, many improved varieties need to be complemented by proper management practices, including fertilizer application $[40,43]$. The fact that only a minority of the households in the panel reported the use of inorganic

\footnotetext{
${ }^{14}$ Preferably, we would have liked to also consider complementary management practices such as crop rotation, intercropping, manure application and fallowing. But our data on these indicators suggest a lot of noise, resulting in almost randomly distributed answers. Therefore, we exclude them.

${ }^{15}$ Improved rice varieties are usually categorized into three groups: The first-generation varieties, which were fertilizer-responsive (released from the mid-1960s to the mid-1970s), the second-generation varieties, which ensured stable yields by also incorporating multiple pest and disease resistance (released from the mid-1970 s to the mid-1980s), and the third-generation varieties, which incorporate better grain quality and stronger host-plant resistance (released from the mid-1980s to the late 1990s) [11]. Varieties that have been around for decades by now might be considered 'local' by the farmers in light of more recently introduced improved varieties.
}

fertilizer could partly explain why the use of improved varieties did not affect production.

In the first period $\left(p_{1}\right)$, there is a strong relationship between higher production and both the usage of fertilizer and of tractor ploughing: Those who used fertilizer both in the reference year and in 2002 had $63 \%$ higher production levels than those households that did not. Also, those who started using fertilizer during this period had levels of production that were $62 \%$ higher than those who never used fertilizer. Similarly, those who ploughed with a tractor both in the reference year and in 2002 had levels of production that were $51 \%$ higher than those who did not use this type of soil preparation. However, neither fertilizer use nor tractor ploughing had any significant effect on production during the other two periods.

The lack of statistical significance for the fertilizer and tractor ploughing variables for the latter period indicates that the relative dynamism in production observed after 2002 has not been significantly driven by fertilizer technology or tractorization. A possible explanation is that farmers applying fertilizer in the latter period used too small quantities to have any impact on production [44].

It could also partly be due to the floods in West Africa in 2008, which had an overall negative (-59\%) impact on rice production, while the 2002 drought in Eastern and Southern Africa did not seem to have had any significant negative effect on rice production. The lack of association between tractor ploughing and rice production might also be related to farmers using other types of techniques for land preparation, such as oxen ploughs. Both these findings warrant further research to explore the specific reasons.

\section{Commercialization variables}

The commercialization variables have strong impact on the production dynamics in all three models. Increases in production are linked to having sold rice as well as to having entered the market or to increased market participation during the considered periods. For instance, the selling of rice both in the reference year and in 2008 had $62 \%$ higher production compared to those households that did not sell at those points in time. Farmers who sold rice both in 2002 and 2008 had about $50 \%$ higher production than those who did not. For households who entered the market or increased their sale of rice in period $p_{2}$, this had a particularly strong impact on production, which was then $62 \%$ higher than in 2002. Moreover, the withdrawal from market activities between 2002 and 2008 or selling smaller quantities of rice in 2008 as compared to 2002 had a significantly negative effect on production, which decreased by $56 \%$. Hence, while household market integration has been important throughout these years in explaining rice production performance, it seems 
Table 8 Estimates of variance component effects by country, village and farm/household effects

\begin{tabular}{|c|c|c|c|}
\hline Variance components & Period $1\left(p_{1}\right): t_{0}$ to $t_{1}$ & Period $1+2\left(p_{1+2}\right): t_{0}$ to $t_{2}$ & Period $2\left(p_{2}\right): t_{1}$ to $t_{2}$ \\
\hline Between-country effects & 0.00 & 0.62 & 0.31 \\
\hline Between-village effects & 0.07 & $0.27^{*}$ & 0.04 \\
\hline Between-household effects & $0.40^{* * *}$ & $0.61^{* * *}$ & $0.77^{* * *}$ \\
\hline
\end{tabular}

* *** To denote test results significant at 5 and $0.1 \%$ levels

to become even more important towards the end of the period.

\section{Macro-level indicators}

We now consider the macro-level policy indicators for all three models. The share of state budget devoted to agriculture and rural development has not had a significant effect on production. This is somewhat surprising, given that, as noted in Table 6, all the countries except for Tanzania have substantially increased their agricultural budgets over time. Our data do not indicate that the new political commitment after the 2003 Maputo declaration has translated into any significant effects benefitting rice farmers. Imports of rice, on the other hand, have a significantly negative effect on rice production in the period $p_{1}$, supporting the hypothesis that domestic production is undermined by cheap imports. However, in relation to the other two models, this effect was not significant. Yet, imports became more important vis-à-vis domestic production for all countries except Tanzania. The reasons for this need to be explored, particularly regarding the effects of higher import tariffs on rice, introduced in the wake of the collapse of the Doha round in the fall of 2006, as well as to rising world market prices for food staples after 2007. These developments may have made domestically produced rice more competitive and thereby provided incentives for farmers to produce more.

The third macro-level variable, GDP per capita, a proxy for economic development in general, had a significant positive effect on rice production in the first period $p_{1}$ as indicated by a $45 \%$ volume increase. The powerful role that agriculture can play in fostering national economic growth during the early stages of development has been well established [45, 46], and more recent literature points to the two-way linkage here, i.e. agriculture can both stimulate and be stimulated by national economic growth, reflecting the interdependence of the agricultural and non-agricultural sectors in the economy [47]. In the specific case of rice, we believe that it is mainly due to the increases in consumer demand as countries develop, caused by factors including higher incomes, changing consumption patterns and urbanization, which in turn creates a production incentive for the rice farmers. However, when considering the two time periods covered by models 2 and 3, variations in GDP per capita do not have any significant effect on production suggesting that the links between production and macro-level developments have weakened over time. Also in the first period, they were more a reflection of global processes and overall national economic development than the state prioritizing the agricultural sector ${ }^{16}$. Hence, our case study does not give any obvious evidence for an ongoing state-driven Green Revolution in rice in SSA.

\section{Distributional variables}

When considering the distributional variables, we see that the gender of the farm manager is not statistically significant in any of the models. This suggests that women farm mangers are not discriminated in relation to rice production, and that their farms perform as well as those of their male counterparts. This is consistent with findings that women and men farmers are equally efficient farm managers [48-52]. It can also be noted that households defined as belonging to the village elite, with other conditions equal, had $36 \%$ higher production than the other households in the first period, $p_{1}$. However, the role of elite membership seems to have dwindled in significance over time and did not affect production outcomes for the other periods. This could be an indication that the earlier elite bias is disappearing and that smallholder farmers are not discriminated against the way they used to be. In addition, it suggests that the recent dynamism in rice markets have brought more smallholder farmers into commercial production, which is also supported by the market entry coefficient in the third model, which is positive and significant at the $1 \%$ level. Similar findings are found also for maize and cereal crops in general for the wider data set $[28,53,54]$. Hence, contrary to the Asian experience, the development during the first decade of the new millennium seems to have been driven more by the market than the state.

Table 8 considers the variance by country, village and household. As can be noted, the largest share of variance is found at the household level and is significant over all the time periods pointing to the importance of variables

\footnotetext{
${ }^{16}$ The first period (covered by model 1) also coincides with a period characterized by very low levels of state net investments in the agricultural sector in most SSA countries.
} 
endogenous to households when explaining production performance.

Although the country effect variation in period $p_{1+2}$ (0.62) may indicate general differences between countries, this is not significant due to the small number of countries. In period $p_{1}$, we do not even see such an indication. In period $p_{1+2}$, there is significant variation in between-village effects on the average rice production, indicating that different villages have different conditions for the production of rice. Such a variation is, however, not observed in period $p_{1}$. This could point to more recently introduced factors that affect production at the village level, e.g. improved water control techniques or improved access to market outlets and processing facilities. In period $p_{2}$, the between-village effect variation is very low and not significant, indicating that the villagedependent effects are rather unchanged over time (from 2002 to 2008) or altered in the same direction and magnitude for a majority of the villages from 2002 to 2008.

\section{Conclusions and implications for policy}

In this article, we have reported on the production performance amongst rice-growing households in five SubSaharan countries: Ghana, Malawi, Nigeria, Tanzania and Mozambique. Using panel data for 317 households interviewed in 2002 and 2008, we have shown that while the mean rice area among the surveyed households has increased by $17 \%$ between 2002 and 2008, rice yields have decreased by $12 \%$ and the mean rice production has remained almost constant with only a $2 \%$ increase. But we also noted substantial cross-country and crossvillage variations, obscured by these figures, suggesting that a mixed pattern of extensification and intensification explain production increases.

We have also identified and evaluated the role of three main types of production drivers: the role of commercial drivers, farm technology and macro-level conditions, studying three time periods: one lasting from on average 1984 (i.e. the reference year) to 2002, one lasting from the reference year to 2008 and one lasting from 2002 to 2008. Of particular interest has been the last period, given increasing political attention to the welfare of smallholders across the continent in recent years, but also to the role of smallholders as key drivers of food production. More generally, the agricultural sector has been identified as the core sector for achieving broad-based development.

Using statistical modelling, we have shown that until 2002, the key drivers of production were a combination of area expansion, market integration, farm technology in terms of fertilizer and tractor ploughing, village elite membership and key macro-level conditions including rice imports and overall economic development in the countries as operationalized by GDP per capita. In relation to the period 2002-2008, we found that production increases were primarily associated with area expansion and commercial drivers. In none of the periods considered did the share of the state budget allocated to agriculture have a significant effect on production.

The fact that there is a strong association between area and production throughout the models, which is not matched by an association between new technology (improved varieties, fertilizer, tractor ploughing) and production in relation to the years 2002 and 2008, suggests that production in later years is more driven by processes of extensification than intensification.

Rice in SSA is still primarily a staple food preferred by urban consumers for whom rice is much more important than national consumption averages suggest. Considering that urbanization levels continue to increase, and that the preference for rice is increasingly spreading to rural areas, the demand for rice may well grow even more rapidly over the coming years, compared to the past few decades [see also 3]. Concerted efforts to increase production of rice are therefore urgently needed.

The role of commercialization in explaining changes in production in the three models suggests that policies that effectively combat the typical negative characteristics of food staple markets in SSA-including uncertainty, discouraging prices, atomism and high transaction costs [55]-hold great potential for driving rice production in the continent in the near future. However, even with improved staple food markets, the possibilities of further growth in the rice sector in SSA are limited without an intensification of production due to the scarcity of available and suitable land for rice production. Eliminating barriers restricting the access to new farm technology for small rice farmers would considerably improve the possibilities of a positive development of rice production in SSA, which in turn would contribute to an improvement of food security and to a reduction of both rural and urban poverty.

\section{Availability of supporting data}

The data set supporting the results of this article is available in the Afrint repository at http://www.keg.lu.se/en/ research/research-projects/current-research-projects/ afrint.

\section{Abbreviations}

Afrint: Africa and intensification; SSA: Sub-Saharan Africa; IRRI: International Rice Research Institute; GDP: gross domestic product; USD: US dollar; IMF: International Monetary Fund.

Authors' contributions

$A A D, G D, B H, M J$ and SN conceived the study and its design. SN, BH and $\mathrm{GD}$ developed the statistical models. SN with support from $\mathrm{BH}$ performed 
the statistical analysis. All authors interpreted the statistical results from the modelling. JBL with support from SN wrote the manuscript. MJ, BH and AAD read and commented on the drafts. All authors read and approved the final manuscript.

\section{Authors' information}

All the authors are members of the Swedish-African research programme Afrint, which studies the drivers of agricultural intensification in nine SubSaharan African countries. SN holds a PhD in statistics and is a research fellow at the Department of Statistics, Lund University, Sweden. Her research interests include statistical techniques for evaluating multivariate multileve data from observational studies and surveys. JBL holds a PhD in social and economic geography and is a research fellow at the Department of Urban and Rural Development, the Swedish University of Agricultural Sciences. Her research interests include studying agricultural intensification and commercialization trajectories in Sub-Saharan Africa from a gender perspective. MJ is Professor of Social and Economic Geography at Lund University, Sweden, currently focusing on rural as well as urban and agricultural development in Sub-Saharan Africa. BH is professor of statistics at Lund University, Sweden. His research interests include statistical techniques for multivariate data analysis. AAD is associate professor of social and economic geography at Lund University, Sweden. Her research interests focus on agrarian change, rural urban household dynamics and gender relations in rural Africa. GD is professor emeritus in sociology at Lund University, Sweden, with longtime experience of agricultural development in Sub-Saharan Africa and India.

\section{Author details}

1 Department of Statistics, Lund University, P.O. Box 743, S-220 07 Lund, Sweden. ${ }^{2}$ Department of Urban and Rural Development, Swedish University of Agricultural Sciences, P.O. Box 7012, S-750 07 Uppsala, Sweden. ${ }^{3}$ Department of Human Geography, Lund University, Sölvegatan 10, S-223 62 Lund, Sweden. ${ }^{4}$ Department of Sociology, Lund University, P.O. Box 114, S-221 00 Lund, Sweden.

\section{Acknowledgements}

The authors wish to acknowledge Mikael Hammarskjöld for valuable assistance and editing support during the final write-up stage. In addition, the authors also acknowledge comments and suggestions put forward at a seminar at the Department of Urban and Rural Development, the Swedish University of Agricultural Sciences, by Andrea Petitt, Katarina Pettersson, Eva Stephansson and Erik Westholm. The article draws on data from the Afrint I and II projects which feature collaboration between researchers in Sweden and nine African countries. These projects were funded through support from the Bank of Sweden Tercentenary Foundation, the Swedish Research Council, the Swedish International Development Cooperation Agency (Sida) and Sida's Research Council for Developing Countries. The Afrint team was led by Göran Djurfeldt, Lund University, Sweden. The country teams for the five African countries considered in this paper were: for Ghana, Ernest Aryeetey, Fred Danku, A. Wayo Seini and V. Kwame Nyanteng, Institute of Statistical, Social and Economic Research (ISSER), Legon-Accra, and Daniel Bruce Sarpong, University of Ghana, Legon-Accra; for Malawi, John M. Kadzandira, James Milner and Wapulumuka O. Mulwafu, University of Malawi, Zomba; for Mozambique, Peter Coughlin, EconPolicy Research Group, Ltd., Maputo; for Nigeria, Olatunji Akande and Olorunfemi Oladapo Ogundele, Nigerian Institute for Social and Economic Research (NISER), Ibadan, Patrick Kormawa, formerly with the International Institute of Tropical Agriculture (IITA), Ibadan, and R. Okechukwu, with the same institute; for Tanzania, Gasper C. Ashimogo, Aida C. Isinika and James E.D. Mlangwa, Sokoine University of Agriculture, Morogoro. The Swedish team consisted of the following researchers from Lund University: Göran Djurfeldt, Rolf Larsson (deceased), Magnus Jirström, Agnes Andersson Djurfeldt, Johanna Bergman Lodin, Cheryl Sjöström, Björn Holmquist and Sultana Nasrin. Member of the Swedish team was also Hans Holmén, Linköping University. Afrint benefitted from a distinguished group of advisors with the following affiliations at the time: Göran Hydén, University of Florida; Oliver Saasa, University of Zambia; Richard Mkandawire, Senior Advisor to New Partnership for Africa's Development (NEPAD); Ruth Oniang'o, Kenyatta University; Deborah Bryceson, University of Oxford; Kjell Havnevik, the Nordic Africa Institute; and Michael Lipton, University of Sussex. All errors and omissions are the authors'.

\section{Compliance with ethical guidelines}

\section{Competing interests}

The authors declare that they have no competing interests.

Received: 10 March 2015 Accepted: 10 August 2015

Published online: 02 September 2015

\section{References}

1. OECD/FAO (2015) OECD-FAO agricultural outlook. OECD Publishing, Paris. doi:10.1787/agr_outlook-2015-en

2. Awika JM, Piironen V, Bean S (2011) Advances in cereal science: implications to food processing and health promotion. American Chemical Society, Washington, DC

3. Mohanty S (2013) Trends in global rice consumption. Rice Today 12(1):44-45

4. Reardon T (1993) Cereals demand in the Sahel and potential impact of regional cereals protection. World Dev 21:17-35

5. Hossain M (2006) Rice in Africa: Can rice help reduce hunger and poverty in sub-Saharan Africa? Rice Today 5(1):41

6. Balasubramanian V, Sie M, Hijmans RJ, Otsuka K (2007) Increasing rice production in Sub-Saharan Africa: challenges and opportunities. Adv Agron. doi:10.1016/S0065-2113(06)94002-4

7. Africa Rice Center (WARDA) (2007) Africa Rice Trends: overview of recent developments in the sub-Saharan Africa rice sector. Africa Rice Center Brief. .Africa Rice Center (WARDA), Cotonou, Benin. http://www.warda.org

8. FAO (2012) Rice market monitor, vol XV, No. 4. FAO Trade and Markets Division, Rome. http://www.fao.org/leadmin/templates/est/COMMMARKETSMONITORING/Rice/Images/RMM/RMM-Nov12.pdf. Accessed 25 Nov 2012

9. IRRI (International Rice Research Institute) (2012) World Rice Statistics. IRRI, Los Banos. http://www.irri.org. Accessed 25 Nov 2012

10. Demont M (2013) Reversing urban bias in African rice markets: a review of 19 National Rice Development Strategies. Glob Food Secur 2(3):172-181

11. Nakano Y, Bamba I, Diagne A, Otsuka K, Kajisa K (2011) The possibility of a rice green revolution in large-scale irrigation schemes in Sub-Saharan Africa. Policy Research Working Paper 5560. The World Bank Development Research Group, Agriculture and Rural Development Team. The World Bank, Washington DC

12. Africa Rice Center (WARDA), FAO and SAA (2008) NERICA ${ }^{\circledR}$ : the New Rice for Africa-A Compendium. In: Somado EA, Guei RG, Keya SO (eds). Africa Rice Center, Cotonou, Benin

13. Rugumamu CP (2014) Empowering smallholder rice farmers in Tanzania to increase productivity for promoting food security in Eastern and Southern Africa. Agric Food Secur 3(7):1-8

14. Akramov K, Malek M (2012) Analyzing profitability of maize, rice, and soybean production in Ghana. Results of PAM and DEA analysis. Ghana Strategy Support Program (GSSP), GSSP Working Paper, No. 0028. International Food Policy Research Institute, Washington, DC. http://www.ifpri. org/sites/default/files/publications/gsspwp28.pdf

15. Angelucci F, Asante-Poku A, Anaadumba P (2013) Analysis of incentives and disincentives for rice in Ghana. Technical notes series. MAFAP, FAO, Rome. http://www.fao.org/fileadmin/templates/mafap/documents/technical_notes/GHANA/GHANA_Technical_Note_RICE_EN_Apr2013.pdf

16. Bamidele FS, Abayomi OO, Esther OA (2010) Economic analysis of rice consumption patterns in Nigeria. J Agric Sci Technol 12:1-11

17. Barreiro-Hurle J (2012) Analysis of incentives and disincentives for rice in the United Republic of Tanzania. Technical notes series. MAFAP, FAO, Rome. http://www.fao.org/fileadmin/templates/mafap/documents/technical_notes/URT/TANZANIA_Technical_Note_RICE_EN_Oct2012.pdf

18. Cadoni P, Angelucci F (2013) Analysis of incentives and disincentives for Rice in Nigeria. Technical notes series. MAFAP, FAO, Rome. http://www.fao. org/fileadmin/templates/mafap/documents/technical_notes/NIGERIA/ NIGERIA_Technical_Note_RICE_EN_Jul2013.pdf 
19. FAO (2011) Nutrition country profile. Republic of Mozambique. Nutrition and Consumer Protection Division, FAO. ftp.fao.org/ag/agn/nutrition/ ncp/moz.pdf

20. Ministry of Agriculture, Republic of Mozambique (2009) National rice development strategy Mozambique. http://www.jica.go.jp/english/ our_work/thematic_issues/agricultural/pdf/mozambique_en.pdf

21. Minot N (2010) Staple food prices in Malawi. Prepared for the Comesa policy seminar on "Variation in staple food prices: Causes, consequence, and policy options", Maputo, Mozambique, 25-26 January 2010 under the African Agricultural Marketing Project (AAMP). Markets, Trade, and Institutions Division, International Food Policy Research Institute, Washington, DC. http://fsg.afre.msu.edu/aamp/seminar_3/AAMP_ Maputo_22_Malawi_ppr.pdf

22. FAOSTAT online database (2014) CountrySTAT. http://faostat.fao.org. Accessed Sep 2014

23. Djurfeldt G, Holmén H, Jirström M, Larsson R (eds) (2005) The African food crisis: Lessons from the Asian green revolution. CAB International, Wallingford

24. Djurfeldt G, Aryeetey E, Isinika AC (eds) (2011) African smallholders: Food crops, markets and policy. CAB International, Wallingford

25. Swedish Research Council (2012) Ethical guidelines, and recommendations on good research practice. http://www.vr.se/inenglish/researchfunding/applyforgrants/generalconditionsforgrantapplications/ethicalgu idelines.4.5adac704126af4b4be280007769.html

26. Deere CD, Alvarado GE, Twyman J (2012) Gender inequality in asset ownership in latin America: female owners vs household heads. Develop Change 43(2):505-530

27. Buvinić M, Gupta GR (1997) Female-headed households and femalemaintained families: are they worth targeting to reduce poverty in developing countries? Econ Dev Cult Change 45(2):259-280

28. Andersson A, Djurfeldt G, Holmquist B, Jirström M, Nasrin S (2011) A new era for Sub-Saharan African agriculture? Changing drivers of maize production. In: Djurfeldt G, Aryeetey E, Isinika AC (eds) African smallholders: food crops, markets and policy. CAB International, Wallingford

29. Jirström M, Andersson A, Djurfeldt G (2011) Smallholders caught in poverty: flickering signs of agricultural dynamism. In: Djurfeldt G, Aryeetey E, Isinika AC (eds) African smallholders_food crops, markets and policy. CABI Publishing, Wallingford, p 2011

30. Bergman Lodin J (2012) Engendered promises, gendered challenges. Changing patterns of labor, control and benefits among smallholder households growing NERICA in Uganda. PhD Thesis. Department of Human Geography, Lund University, Lund

31. Chinsinga B, Poulton C (2014) Beyond technocratic debates: the significance and transience of political incentives in the malawi farm input subsidy programme (FISP). Develop Policy Rev. 32(2):123-150

32. Mbamalu M (2015) Import quota debate: Crisis looms in Nigeria's rice value chain. The guardian. http://www.ngrguardiannews.com/ business/194296-import-quota-debate-crisis-looms-in-nigeria-s-ricevalue-chain. Accessed 17 Feb 2015

33. Public Affairs -Nigeria (2014) Jonathan: Nigeria will join league of rice exporters by 2017. http://publicaffairs.gov.ng/jonathan-nigeria-will-joinleague-of-rice-exporters-by-2017/. Accessed 17 Feb 2015

34. THISDAY Live (2013) Odds against 2015 ban on rice importation. http:// www.thisdaylive.com/articles/odds-against-2015-ban-on-rice-importation/151269/. Accessed 11 Nov 2013

35. Oryza.com (2014) Nigeria lowers import duty on rice under new threeyear fiscal policy measure. http://www.oryza.com/news/rice-news/nigeria-lowers-import-duty-rice-under-new-three-year-fiscal-policy-measure. Accessed 17 Feb 2015

36. Agritrade (2014) Nigeria further extends levy concessions to support rice sector backward linkages. CTA, Technical Centre for Agriculture and Rural Cooperation (ACP-EU). http://agritrade.cta.int/en/layout/set/print/Agriculture/Commodities/Rice/Nigeria-further-extends-levy-concessions-tosupport-rice-sector-backward-linkages. Accessed 17 Feb 2015

37. Agritrade (2014) Trade policy reforms and investments in Nigerian rice sector continue. 26 Oct. CTA, Technical Centre for Agriculture and Rural Cooperation (ACP-EU). http://agritrade.cta.int/en/layout/set/print/ Agriculture/Commodities/Rice/Trade-policy-reforms-and-investments-inNigerian-rice-sector-continue. Accessed 17 Feb 2015
38. Childs N (2014) Rice outlook. Economic Research Service, United States Department of Agriculture (USDA), Situation and Outlook, RCS-14 h. http://www.ers.usda.gov/media/1547831/rcs-14h.pdf. Accessed 17 Feb 2015

39. Glewwe P, Hall G (1998) Are some groups more vulnerable to macroeconomic shocks than others? Hypothesis tests based on a panel from Peru. J Dev Econ 56:181-206

40. Barker R, Herdt RW, Rose B (1985) The rice economy of Asia. Johns Hopkins University Press, Washington DC

41. Mine S (2012) Results of Pilot testing of a varietal identification protocol for pigeon pea in Tanzania's Northern Zone. Report to CGIAR Standing Panel in Impact Assessment

42. Heisey PW, Akhter MR, Tetlay KA, Ahmed Z, Ahmed M, Sattar A, Khattak AK (1987) Monitoring wheat varieties grown in Pakistan: Objectives, methods, and results from three major copping systems, 1985/86. PARC/ CIMMYT, Islamabad

43. Hayami Y, Ruttan VW (1985) Agricultural development-an international perspective. Johns Hopkins, Baltimore

44. Ezui KS, Daudu CK, Mando A, Kudi MT, Odunze OC, Adeosun JO, Amapu IY, Tarfa B, Sambo I, Bello I, Dangbegnon C (2010) Informed site-specific fertilizer recommendation for upland rice production in northern guinea savannah of Nigeria. Proceedings from the Second Africa Rice Congress Bamako, Mali, Innovation and Partnerships to realize Africa's Rice Potential. http://www.africaricecenter.org/warda/arc.htm

45. Johnston BF, Mellor JW (1961) The role of agriculture in economic development. Am Econ Rev 51(4):566-593

46. Mellor JW (ed) (1995) Agriculture on the road to industrialization. International Food Policy Research, InstituteWashington, D.C

47. Haggblade S, Hazell PBR, Dorosh PA (2007) Sectoral growth linkages between agriculture and the rural nonfarm economy. In: Haggblade S, Hazell P, Reardon T (eds) Transforming the Rural nonfarm economy: opportunities and threats in the developing world. Johns Hopkins University Press, Baltimore

48. Quisumbing A (1996) Male-female differences in agricultural productivity: methodical issues and empirical evidence. World Dev 24(10):1579-1595

49. Dey Abbas J (1997) gender asymmetries in intra-household resource allocation in Sub-Saharan Africa: Some policy implications for land and labor productivity. In: Haddad L, Hoddinott J, Alderman H (eds) Intra-household resource allocation in development countries: models, methods, policy International Food Policy Research. Johns Hopkins University Press, Baltimore, pp 249-262

50. Diagne A, Gnonna Midingoyi SK, Kinkingninhoun F (2009) The Impact of NERICA adoption on rice yield in West Africa: evidence from four countries. Mimeo. Africa Rice Center, Cotonou, Benin

51. Andersson Djurfeldt A, Djurfeldt G, Bergman Lodin J (2013) Geography of gender gaps: regional patterns of income and farm-nonfarm interaction among male- and female-headed households in eight African countries. World Development 48:32-47

52. Bergman Lodin J, Paulson S, Jirström M (2014) NERICA upland rice: seeds of change for female-headed households in Uganda? Cult Agric Food Environ CAFE 36(2):129-141

53. Andersson Djurfeldt A (2013) African Re-agrarianization? Accumulation or Pro-poor Agricultural Growth? World Dev 41:217-231

54. Andersson Djurfeldt A, Djurfeldt G (2013) Structural transformation and African smallholders: drivers of mobility within and between the farm and non-farm sectors for eight countries. Oxf Dev Stud 41(3):281-306

55. Poulton C, Kydd J, Dorward A (2006) Overcoming market constraints on pro-poor agricultural growth in sub-Saharan Africa. Dev Policy Rev 24(3):243-277

56. The USDA Foreign Agricultural Service's Production, Supply and Distribution (PSD) online database (2014). https://apps.fas.usda.gov/psdonline/. Accessed Oct 2014

57. The World Bank online population database (2014). http://data.worldbank.org/indicator/SP.POP.TOTL. Accessed Oct 2014

58. Chanyanov AV (1996) AV Chayanov on the theory of peasant economy. In: Kerblay TB, Smith REF, Richard DI (eds) The American Economic Association Translation Series, Homewood, Illinois 